\title{
The Morphometry and Morphology of the Foramen Magnum In Age And Sex Determination Within The South African Black Population Utilizing Computer Tomography (CT) Scans
}

\author{
Morfometría y Morfología del Foramen Magnum en la determinación de edad y Sexo \\ Dentro de la Población Negra Sudafricana Mediante Tomografía Computarizada (TC)
}

\author{
M. Moodley; C. Rennie; L. Lazarus \& K. S. Satyapal
}

\begin{abstract}
MOODLEY, M.; RENNIE, C.; LAZARUS, L. \& SATYAPAL, K. S. The morphometry and morphology of the foramen magnum in age and sex determination within the South African Black population utilizing computer tomography (CT) scans. Int. J. Morphol., $37(1): 251-257,2019$.
\end{abstract}

SUMMARY: The morphology and morphometry of the foramen magnum aid forensic studies in identifying unknown individuals according to age and sex. Moreover, these parameters of the foramen magnum have clinical relevance to surgeons in the transcondylar approach. This study aimed to analyze the morphometry and morphology in relation to the age and sex of individuals within the South African Black population, utilizing computerized tomography images. The use of computerized tomography images allowed for accurate morphometric diameters using the SLICER 3-D software version 4.7.0. Radiological images also provide a patient's clinical history. Thus, the process of exclusion in respect to patients with pathological conditions of the skull is achieved. The sample studied included 150 computerized tomography images ( 93 males and 57 females) arranged according to age cohorts (children aged 1-12 years, adolescents aged 13-17 years and adults aged 18-25 years). The morphometric parameters viz. antero-posterior diameter, transverse diameter and area of the foramen magnum was analyzed in relation to age and sex. The morphological variations of the foramen magnum was simultaneously observed between males and females and within the age groups. The objective of this study were to improve data on the morphological and morphometric parameters of the foramen magnum in the South African Black population. This study also attempted to associate the morphological and morphometric parameters of the foramen magnum with age and sex determination.

KEY WORDS: Computer tomography; Morphometry; Morphology; Age, Males Females.

\section{INTRODUCTION}

Identification of unknown individuals is fundamental in forensic studies, and is based upon the determination of sex, age, ethnicity and stature of individuals (Vedanayagam \& Sathyamurthy, 2015; Raikar et al., 2016). The skull is a suitable skeletal structure used in determining the factors of identification (Pires et al., 2016). Forensic anthropologists study the morphology and morphometry of cranial structures such as the glabella, nasal aperture and even the foramen magnum in terms of sex and age determination (Manoel et al., 2009; Gapert et al., 2009; Pires et al.).

The foramen magnum is the most conspicuous structure situated in the of the occipital bone, in the skull (Standring, 2016). It contains vital neurological structures that relay information to and from the brain and spinal cord (Standring).
Standard textbooks describe the foramen magnum as oval shaped (Standring). However, studies show different morphological shapes of the foramen magnum in individuals exist, varying from round to even irregular (Burdan et al., 2012; Shaikh \& Kulkarni, 2015). The variation in morphology is said to have a significance to ancestry and different populations (Chethan et al., 2012). Some authors also reported that the morphological variations could be related to the age and sex of an individual (Natsis et al., 2013; Shaikh \& Kulkarni).

Cranial morphometry aids human studies that involve age and sex determination (Ganapathy et al., 2014). Recent reports from studies state that the morphometric diameters of the foramen magnum are greater in males than females (Uthman 
MOODLEY, M.; RENNIE, C.; LAZARUS, L. \& SATYAPAL, K. S. The morphometry and morphology of the foramen magnum in age and sex determination within the South African Black population utilizing computer tomography (CT) scans. Int. J. Morphol., 37(1):251-257, 2019.

et al., 2012; Ganapathy et al.; Vedanayagam \& Sathyamurthy; Raikar et al.). Shaikh \& Kulkarni studied the morphometric parameters in relation to age and reported an increase in diameters with an increase in age. Therefore, knowledge on the dimensions and various shapes of the foramen magnum is important to forensic experts when determining the age and sex of an individual (Shaikh \& Kulkarni).

Moreover, the foramen magnum is clinically important because the vital structures that pass through may endure compression in cases such as: foramen magnum herniation; meningiomas and achondroplasia (Shepur et al., 2014). In these circumstances knowledge of the dimensions of the foramen magnum has clinical and radiological relevance, as it helps surgeons in the transcondylar surgical procedure to relieve compression (Murshed et al., 2003).

This study analyzed the parameters of the foramen magnum in the South African Black population, using computerized tomography images. The advantages of using computerized tomography images includes noninvasive methods of accurately observing the shape and size of the foramen magnum (Chandramani et al., 2015). Radiological images also include a patient's clinical history allowing for individuals with trauma to the skull to be excluded from the study (Chandramani et al.). This study aims to improve data
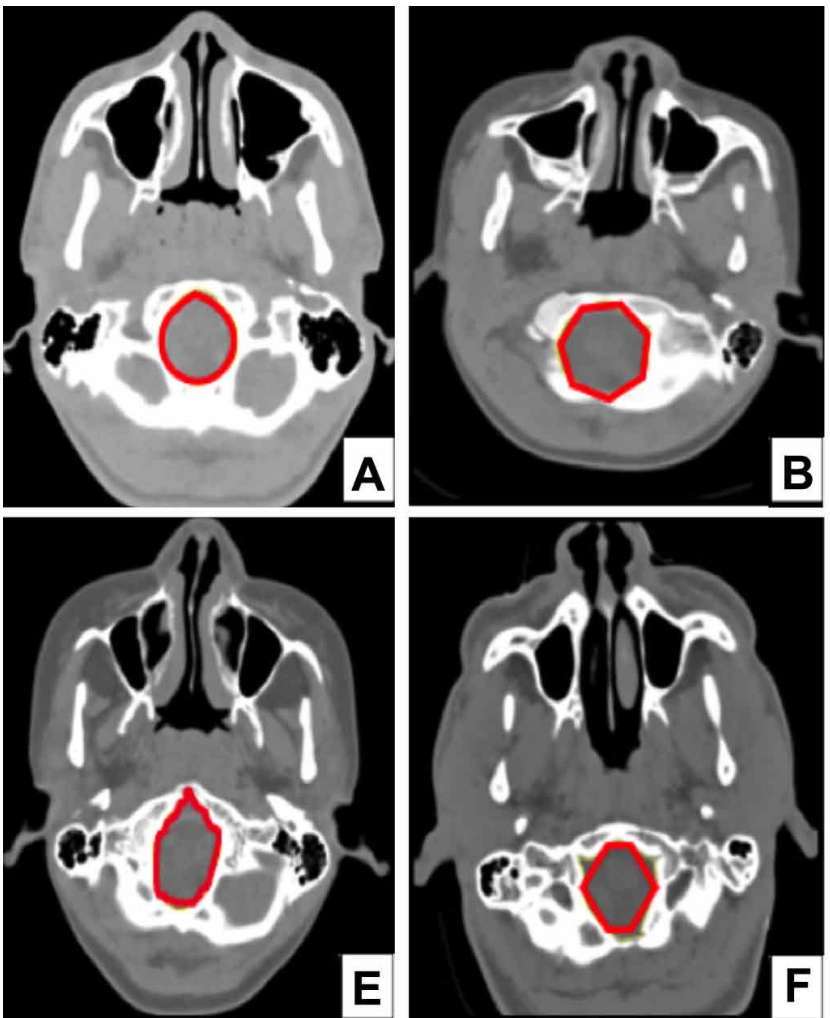

on the morphology and morphometry of the foramen magnum in the South African Black population, using computerized tomography images.

\section{MATERIAL AND METHOD}

This study was a retrospective review of one hundred and fifty computerized tomography images from the department of Clinical Anatomy in the School of Laboratory medicine and Medical Sciences, University of KwaZuluNatal. Ethical clearance was obtained from the Biomedical Research Ethics Committee. The sample consisted of males $(n=93)$ and females $(n=57)$, and was divided into three age categories viz: children 1-12 years $(n=50)$, Adolescents 1317 years $(n=50)$ and Adults $18-25$ years $(n=50)$ years. The dicom images of the computerized tomography scans were imported and analyzed using the free Slicer 3-D software version 4.7.0 (www.3Dslicer.org; Accessed-24 June 2017). Inclusion criteria: Computerized tomography images with a $1 \mathrm{~mm}$ slice thickness, South African Black patients between the ages of one and twenty-five years. Exclusion criteria: Patients with a history of skull trauma, or skull pathologies such as Achondroplasia or Arnold Chiari syndrome, that could compromise the accuracy of the study.
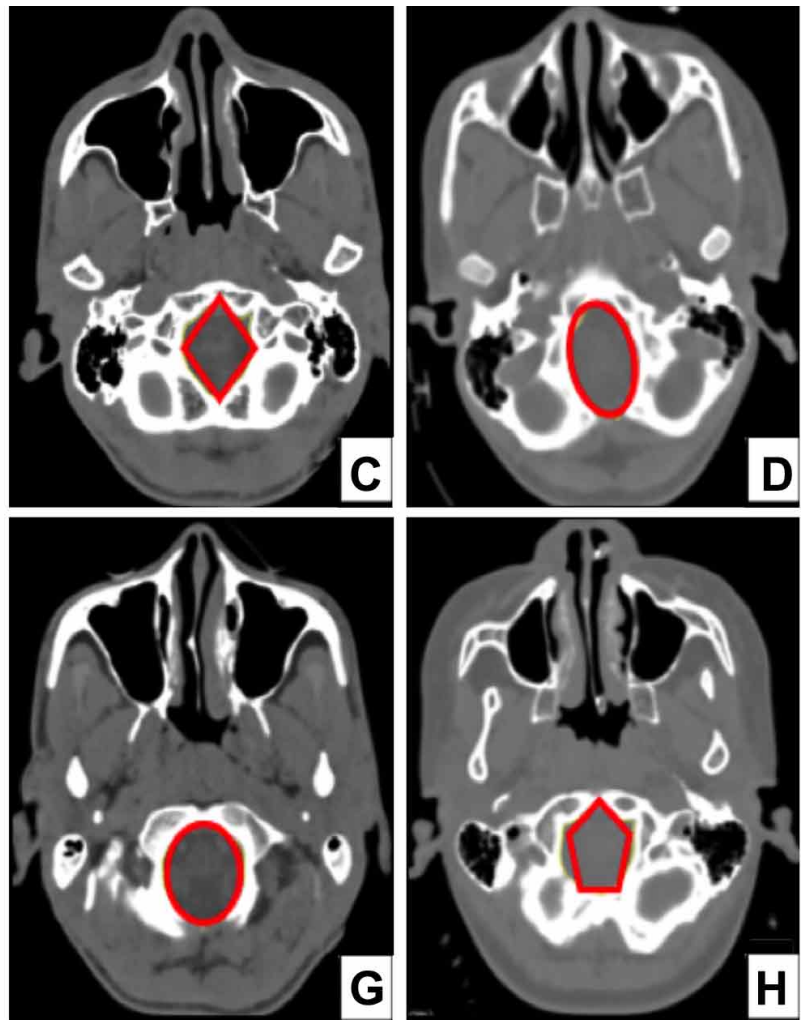

Fig. 1. Morphological variations observed in the South African Black population. Key: A-Egg-shaped; B- Hexagonal; C- Tetragonal; D-Oval; E-Irregular; F- Hexagonal; G- Round and H- Pentagonal. 
Morphological and Morphometrical analysis. The axial view of the computerized tomography scans was used in conjunction with the measuring tool on SLICER 3-D to analyze the antero-posterior and transverse diameters $(\mathrm{mm})$ of the foramen magnum. The longest antero-posterior diameters and widest transverse diameters of the foramen magnum was measured on the CT scans (Fig. 1). An average of three trials for each diameter was recorded. The anteroposterior and transverse diameters were used in the Radinsky's formula- $1 / 4 \times \mathrm{AP} \times \mathrm{TD}$ to calculate the area $\left(\mathrm{mm}^{2}\right)$ of the foramen magnum. A macroscopic system based on the number of sides in the outline of the shape was used to classify the morphology of the foramen magnum.

Statistical analysis. The IBM Statistical Package for the Social Sciences (SPSS) version 24 was used to statistically analyze results on the morphology and morphometry of the foramen magnum in age and sex determination. The Pearson's Chi-square test was adopted to analyze the frequency of the morphological parameters. The ANOVA one -way method was utilized to analyze the significance of the morphometric parameters viz antero-posterior, transverse diameters and area in age, and the independent t-test was used to analyze the significance of the morphometric parameters between males and females. Any p-value less than 0.05 was interpreted as statistically significant, whilst values greater were not statistically significant.

\section{RESULTS}

Morphological analysis. The foramen magnum was studied, and eight varying morphological shapes were identified and reported: egg-shape; heptagonal shape; hexagonal shape; irregular; oval shape; pentagonal shape; round shape; and tetragonal shape. The most common shape observed in the South African Black population was the egg-shape $(20.67 \%)$.

Descriptive analysis of the eight variable shapes of the foramen magnum observed between males and females is represented in a cross-tabulated frequency table as a count and percentage (Table I). The egg-shaped was observed in $20.67 \%$ subjects (males $12 \%$ and females $8.67 \%$ ), heptagonal shape in $18.67 \%$ (males $11.33 \%$ and females $7.33 \%$ ), hexagonal shape in $16 \%$ subjects (males $9.33 \%$ and females $6.67 \%$ ), tetragonal shape in $12 \%$ subjects (males $8.67 \%$ and females $3.33 \%$ ), round shape in $9.33 \%$ (males $7.33 \%$ and $2 \%$ females), irregular shape $8.67 \%$ subjects (males $4 \%$ and females $4.67 \%$ ) and oval shape in $1.33 \%$ subjects $(0.67 \%$ in both males and females). The Pearson chi-square test was used to show the association of the varying morphological types in age and sex. The Chi-square value presented as 0.736 , and showed no association between the shape of the foramen magnum and sex.

Table I. Cross-tabulation of morphological variations between males and females.

\begin{tabular}{lccc}
\hline \multicolumn{1}{c}{ Shape } & Sex & Total \\
& Male n $(\%)$ & Female n $(\%)$ & \\
\hline Egg-shaped & $18(12 \%)$ & $13(8.67 \%)$ & $31(20.67 \%)$ \\
Heptagonal & $17(11.33 \%)$ & $11(7.33 \%)$ & $28(18.67 \%)$ \\
Hexagonal & $14(9.33 \%)$ & $10(6.67 \%)$ & $24(16 \%)$ \\
Irregular & $6(4 \%)$ & $7(4.67 \%)$ & $13(8.67 \%)$ \\
Oval & $1(0.67 \%)$ & $1(0.67 \%)$ & $2(1.33 \%)$ \\
Pentagonal & $13(8.67 \%)$ & $7(4.67 \%)$ & $20(13.33 \%)$ \\
Round & $11(7.33 \%)$ & $3(2 \%)$ & $14(0.93 \%)$ \\
Tetragonal & $13(8.67 \%)$ & $5(3.33 \%)$ & $18(12 \%)$ \\
Total & $93(62 \%)$ & $57(38 \%)$ & $150(100 \%)$ \\
p value & & 0.736 & \\
\hline
\end{tabular}

Table II. Cross-tabulation of morphological variations in groups.

\begin{tabular}{lcccc}
\hline Shape & & \multicolumn{2}{c}{ Age groups n $(\%)$} \\
& $1-12$ years & $13-17$ years & $18-25$ years & Total \\
\hline Egg-Shaped & $13(8.67 \%)$ & $15(10 \%)$ & $3(2 \%)$ & $31(20.67 \%)$ \\
Heptagonal & $6(4 \%)$ & $12(8 \%)$ & $10(6.67 \%)$ & $28(18.67 \%)$ \\
Hexagonal & $6(4 \%)$ & $7(4.67 \%)$ & $11(7.33 \%)$ & $24(16 \%)$ \\
Irregular & $8(5.33 \%)$ & $0(0 \%)$ & $5(3.33 \%)$ & $13(8.67 \%)$ \\
Oval & $1(0.67 \%)$ & $0(0 \%)$ & $1(0.67 \%)$ & $2(1.33 \%)$ \\
Pentag onal & $7(4.67 \%)$ & $5(3.33 \%)$ & $8(5.33 \%)$ & $20(13.33 \%)$ \\
Round & $2(1.33 \%)$ & $7(4.67 \%)$ & $5(3.33 \%)$ & $14(9.33 \%)$ \\
Tetragonal & $7(4.67 \%)$ & $4(2.67 \%)$ & $7(4.67 \%)$ & $18(12 \%)$ \\
Total & $50(33.33 \%)$ & $50(33.33 \%)$ & $50(33.33 \%)$ & $150(100 \%)$ \\
p value & & \multicolumn{3}{c}{0.015} \\
\hline
\end{tabular}


MOODLEY, M.; RENNIE, C.; LAZARUS, L. \& SATYAPAL, K. S. The morphometry and morphology of the foramen magnum in age and sex determination within the South African Black population utilizing computer tomography (CT) scans. Int. J. Morphol., 37(1):251-257, 2019.

These variable shapes of the foramen magnum were simultaneously observed amongst three age categories: children (1-12); adolescents (13-17); and adults (18-25) and reported in (Table II). The egg-shaped foramen magnum was reported in children as $8.67 \%$, adolescents $10 \%$, adults 2 $\%$; the heptagonal shape in children $4 \%$, adolescents $8 \%$, adults $6.67 \%$; hexagonal shape in children $4 \%$, adolescents $4.67 \%$, adults $7.33 \%$; irregular shape in children $5.33 \%$, adolescents $0 \%$, adults $3.33 \%$; oval shape in children 0.67 $\%$, adolescents $0 \%$, adults $0.67 \%$; pentagonal shape in children $4.67 \%$, adolescents $3.33 \%$, adults $5.33 \%$; round shape in children $1.33 \%$, adolescents $4.67 \%$, adults 3.33 $\%$; and the tetragonal shape in children $4.67 \%$, adolescents $2.64 \%$ and adults $12 \%$. The most common shape observed in children (egg-shape $8.67 \%$ ), adolescents (10\%) and adults (hexagonal $7.33 \%$ ). The was an association between age and shape of the foramen magnum ( $\mathrm{P}$ value-0.015).

Morphometric analysis. The present study recorded the mean antero-posterior and transverse diameters in the South African black population as $35.15 \pm 2.74 \mathrm{~mm}$ and $28.86 \pm 2.35$ $\mathrm{mm}$, respectively (Table III). The maximum antero-posterior diameter observed in this population is $41.47 \mathrm{~mm}$ whilst the minimum is $26.63 \mathrm{~mm}$. The maximum and minimum transverse diameter in this study was observed as $37.10 \mathrm{~mm}$ and $23.75 \mathrm{~mm}$ respectively. The mean area in this study was recorded as $800.63 \pm 116.59 \mathrm{~mm}^{2}$, whilst the maximum and minimum area of the foramen magnum was $1132.96 \mathrm{~mm}^{2}$ and $501.53 \mathrm{~mm}^{2}$ respectively.

The morphometric parameters such as antero-posterior, transverse diameters and area was analyzed in relation to the sex of individuals in the studied sample (Table III). The mean transverse diameter and standard deviation of the foramen magnum in males and females is $29.47 \pm 2.16 \mathrm{~mm}$ and $27.86 \pm 2.31 \mathrm{~mm}$ respectively. The t-test was used to calculate the significance of the transverse diameter between sexes, and the p-value is $<0.001$. The mean antero-posterior diameter and standard deviation of the foramen magnum in males and females is $35.66 \pm 2.77 \mathrm{~mm}$ and $34.32 \pm 2.48 \mathrm{~mm}$ respectively. The t-test calculated a p-value that is $<0.05$. The transverse and antero-posterior diameters showed a difference between males and females, that was statistically significant. The area of the foramen magnum was calculated using the Radinsky formula. Statistical analysis revealed that the mean area in males $\left(828.92 \pm 113.25 \mathrm{~mm}^{2}\right)$ was statistically greater than in females $\left(754.46 \pm 107.69 \mathrm{~mm}^{2}\right)$ (p-value<0.001) (Table III).

The same morphometric parameters of anteroposterior,transverse diameters and area was analyzed in relation to the three age groups investigated in this study

Table III. Morphometric diameters and area in males and females.

\begin{tabular}{llccccc}
\hline & Sex & Sample & Mean $(\mathrm{mm}) \pm \mathrm{SD}$ & $\begin{array}{c}\text { Minimum } \\
(\mathrm{mm})\end{array}$ & $\begin{array}{c}\text { Maximum } \\
(\mathrm{mm})\end{array}$ & p-value \\
\hline Transverse & Male & 93 & $29.47 \pm 2.16$ & 24.70 & 35.07 & $\mathrm{P}<0.001$ \\
diameter & Female & 57 & $27.86 \pm 2.31$ & 23.75 & 37.10 & \\
& Total & 150 & $28.86 \pm 2.35$ & 23.75 & 37.10 & \\
Antero- & Male & 93 & $35.66 \pm 2.77$ & 28.43 & 41.57 & 0.03 \\
posterior & Female & 57 & $34.32 \pm 2.48$ & 26.63 & 38.87 & \\
diameter & Total & 150 & $35.15 \pm 2.74$ & 26.63 & 41.47 & \\
Area (mm_) & Male & 93 & $828.92 \pm 113.25$ & 551.81 & 1099.54 & $\mathrm{P}<0.001$ \\
& Female & 57 & $754.46 \pm 107.69$ & 501.53 & 1132.96 & \\
& Total & 150 & $800.63 \pm 116.59$ & 501.53 & 1132.96 & \\
\hline
\end{tabular}

Table IV. The morphometric diameters and area in age groups.

\begin{tabular}{clccccc}
\hline & \multicolumn{1}{c}{ Ages (years) } & Sample & $\begin{array}{c}\text { Mean }(\mathrm{mm}) \pm \\
\text { SD }\end{array}$ & $\begin{array}{c}\text { Minimum } \\
(\mathrm{mm})\end{array}$ & $\begin{array}{c}\text { Maximum } \\
(\mathrm{mm})\end{array}$ & $\mathrm{p}$-value \\
\hline Transvers & Children (1-12) & 50 & $27.714 \pm 1.86$ & 23.75 & 31.00 & $\mathrm{P}<0.001$ \\
e diameter & Adolescents (13-17) & 50 & $28.60 \pm 1.85$ & 25.33 & 32.83 & \\
& Adults (18-25) & 50 & $30.27 \pm 2.55$ & 25.33 & 37.10 & \\
Antero- & Children (1-12) & 50 & $33.13 \pm 2.83$ & 26.63 & 37.23 & $\mathrm{P}<0.001$ \\
posterior & Adolescents (13-17) & 50 & $35.23 \pm 1.66$ & 31.57 & 39.83 & \\
diameter & Adults (18-25) & 50 & $37.09 \pm 2.00$ & 33.00 & 41.57 & \\
Area (mm_) & Children (1-12) & 50 & $724.23 \pm 99.16$ & 501.53 & 906.90 & $\mathrm{P}<0.001$ \\
& Adolescents (13-17) & 50 & $792.98 \pm 79.01$ & 649.00 & 1003.55 & \\
& Adults (18-25) & 50 & $884.66 \pm 109.72$ & 666.36 & 1132.96 & \\
\hline
\end{tabular}


MOODLEY, M.; RENNIE, C.; LAZARUS, L. \& SATYAPAL, K. S. The morphometry and morphology of the foramen magnum in age and sex determination within the South African Black population utilizing computer tomography (CT) scans. Int. J. Morphol., 37(1):251-257, 2019.

using the one-way ANOVA test (Table IV). The mean transverse diameter and standard deviation was recorded in children, adolescents and adults as $27.714 \pm 1.86 \mathrm{~mm}$, $28.60 \pm 1.85 \mathrm{~mm}$ and $30.27 \pm 2.55 \mathrm{~mm}$, respectively $(\mathrm{P}<0.001)$. The mean antero-posterior diameter and standard deviation was recorded in children, adolescents and adults as $33.13 \pm 2.83 \mathrm{~mm}, 35.23 \pm 1.66 \mathrm{~mm}$ and $37.09 \pm 2.00$, respectively $(\mathrm{P}<0.001)$. The area in children, adolescents and adults was documented as $724.23 \pm 99.16 \mathrm{~mm}^{2}$, $792.98 \pm 79.01 \mathrm{~mm}^{2}$ and $884.66 \pm 109.72 \mathrm{~mm}^{2}$ respectively $(\mathrm{P}<0.001)$ (Table IV).

\section{DISCUSSION}

Morphological analysis. Many researchers observed varying shapes of the foramen magnum (Zaidi \& Dayal, 1988; Loyal et al., 2013; Ganapathy et al.; Cirpan et al., 2016). The present study macroscopically observed eight varying shapes of the foramen magnum in the South African Black population. These shapes are reported as egg-shape, oval, round, irregular, tetragonal, pentagonal, hexagonal and heptagonal.

Recent studies reported that the morphological variations of the foramen magnum are indicative of ancestral variability (Sharma et al., 2015). However, standard textbooks describe the foramen magnum as oval in shape (Chaurasia, 2004). Zaidi \& Dayal reported that oval shape in $64 \%$ of the Turkish population. A few recent studies also reported that the oval shape was most common in different populations (Ganapathy et al.; Cirpan et al.). However, Fathima and Babu (2016) reported the egg-shape (36\%) was most common in the Indian population. Similarly, the present study reports the egg-shape (20.67\%) foramen magnum as most common. The present study also observed a heptagonal shape that was only observed in studies by Aragão et al. (2014) in Brazil and Shaikh \& Kulkarni in India.

Researchers have also investigated the morphological variations of the foramen magnum in age and sex determination (Shaikh \& Kulkarni). The present study shows that there is no statistical difference in the morphology between sexes ( $p>0.05)$. The egg-shape was most frequently observed in both males (12\%) and females $(8.67 \%)$. Similar observations were reported by Burdan et al. in Poland as the wide-oval shape was most common in both males and females. Many other studies reported no difference in variations of shape in the sex of an individual. However, Natsis et al. documented a statistical difference between males and females. Natsis et al. observed the egg-shape as most common in males $(23.4 \%)$ whilst the two-semicircle shape was most common in females $(33.3 \%)$.
Shaikh \& Kulkarni investigated the varying shapes of the foramen magnum between ages and observed morphological differences in fetuses, adolescents and adults. The present study did not observe any differences between children $(8.67 \%)$ and adolescents $(10 \%)$, as the egg-shape occurred frequently in both age groups. However, in the adult age group the most common shape was the hexagonal shape $(7.33 \%)$. Whilst, the egg-shape was present in only $2 \%$ of adults. The Pearson chi-square test presented a statistical difference between morphology and the age of an individual $(\mathrm{p}<0.05)$.

The present findings state that the morphological parameters are important in age determination but not in sex determination.

Morphometric analysis. Many studies analyzed the antero-posterior, transverse diameters and area of the foramen magnum (Uysal et al., 2005; Shepur et al.; Ganapathy et al.; Sharma et al.). These parameters are important for forensic investigations and anthropological examinations of unknown individuals (Manoel et al.; Uthman et al.).

A morphometric analysis of the antero-posterior and transverse diameters in the present study revealed overall maximum and minimum values of $(41.47 \mathrm{~mm}, 26.63 \mathrm{~mm})$ and $(37.1 \mathrm{~mm}, 23.75 \mathrm{~mm})$, respectively. The overall mean antero-posterior diameter $(35.15 \pm 2.74 \mathrm{~mm})$ was found to be greater than the mean transverse diameter in this study $(28.86 \pm 2.35 \mathrm{~mm})$. Similar findings were reported in a series of other studies (Gruber et al., 2009; Natsis et al.; Loyal et al.; Patel \& Mehta, 2014; Ganapathy et al.). However, Vedanayagam \& Sathyamurthy in India observed a greater overall transverse diameter.

The foramen magnum is a prominent structure in the base of the skull, and it shows morphometric differences between males and females (Raikar et al.). Burdan et al. in Poland reported a statistical difference in the morphometric diameters between males and females from computerized tomography images. The antero-posterior and transverse diameters in males and females was $(37.06 \pm 3.07 \mathrm{~mm}, 32.98 \pm 2.78 \mathrm{~mm})$ and $(35.47 \pm 2.60 \mathrm{~mm}$, $30.95 \pm 2.71 \mathrm{~mm}$ ), respectively (Burdan et al.). The present study revealed that the mean antero-posterior diameter in males $(35.66 \pm 2.77 \mathrm{~mm})$ was greater than females $(34.32 \pm 2.48 \mathrm{~mm})$. The transverse diameter in males $(29.47 \pm 2.16 \mathrm{~mm})$ is also greater than females $(27.86 \pm 2.31$ $\mathrm{mm}$ ). Many authors reported sex dimorphism in both morphometric diameters of the foramen magnum, with the greater diameters present in males (Uthman et al.; Natsis et al.; Ganapathy et al.). 
MOODLEY, M.; RENNIE, C.; LAZARUS, L. \& SATYAPAL, K. S. The morphometry and morphology of the foramen magnum in age and sex determination within the South African Black population utilizing computer tomography (CT) scans. Int. J. Morphol., 37(1):251-257, 2019.

In this study, statistcial significance in sex was found in both the antero-posterior diameter $(\mathrm{p}<0.05)$ and the transverse diameter $(\mathrm{p}<0.001)$. However, other studies reported that only the transverse diameter showed statistical significance between males and females (Vedanayagam \& Sathyamurthy; Manoel et al.). In another study, Loyal et al. observed that the antero-posterior and transverse diameters in males $(4 \pm 0.65 \mathrm{~cm}, 3.8 \pm 0.7 \mathrm{~cm})$ were greater than females $(3.4 \pm 0.65 \mathrm{~cm}, 2.8 \pm 0.7 \mathrm{~cm})$, respectively. However, no statistical significance was found between males and females (Loyal et al. ).

The current research also studied the area of the foramen magnum in relation to sex and age. The overall mean area of this study was $800.63 \pm 116.59 \mathrm{~mm}^{2}$. In males the mean area was greater $\left(828.92 \pm 113.25 \mathrm{~mm}^{2}\right)$ than in females (754.46 $\left.\pm 107.69 \mathrm{~mm}^{2}\right)$. Günay \& Altinkök (2000) in Turkey also reported a greater mean area in males $(909.91 \pm 126.02$ $\mathrm{mm}^{2}$ ) than females $\left(819.01 \pm 117.24 \mathrm{~mm}^{2}\right)$. More recent studies reported findings that agreed with Günay \& Altinkök (Murshed et al.; Uthman et al.; Burdan et al.; Shepur et al.; Pires et al.).

Chandramani et al. conducted a study on the morphometric diameters of the foramen magnum in relation to age of Indian subjects (8-79 years) and reported no significant difference in age. However, another study in India found a statistical difference in the diameters in relation to age (Shaikh \& Kulkarni). The current study observed $\mathrm{f}$ indings similar to Shaikh \& Kulkarni, as the diameters statistically increased from children (aged 1-12 years) to adolescents (aged 13-17 years) and through to adults (aged $18-25$ years $)(p<0.001)$. The present study reports the mean antero-posterior diameter in these age groups viz children $(33.13 \pm 2.83 \mathrm{~mm})$, adolescents $(35.23 \pm 1.66 \mathrm{~mm})$ and in adults $(37.09 \pm 2.00 \mathrm{~mm})$. The maximum antero-posterior diameter occurred in the adult age group, whilst the minimum occurred in the youngest age group i.e. children. The mean transverse diameters presented in children $(27.714 \pm 1.86$ $\mathrm{mm})$, adolescents $(28.60 \pm 1.85 \mathrm{~mm})$ and in adults $(30.27 \pm 2.55 \mathrm{~mm})$. The maximum and minimum transverse diameter occurred in adults and children respectively.

Previous research did not study the area of the foramen magnum in relation to age. This study investigated the area of the foramen magnum within children (724.23 \pm 99.16 $\mathrm{mm}^{2}$ ), adolescents $\left(792.98 \pm 79.01 \mathrm{~mm}^{2}\right)$ and adults $\left(884.66 \pm 109.72 \mathrm{~mm}^{2}\right)$. The morphometric area was found to be statistically significant within these age groups $(\mathrm{p}<0.001)$.

The results of this study reveal that morphometric diameters and dimensions is important in sex and age determination.

\section{CONCLUSION}

The morphometric diameters and area of the foramen magnum showed significant differences in the age and sex of an individual. However, in this study the morphology of the foramen magnum only presented significant differences in age and not in the sex of an individual in this population group.

MOODLEY, M.; RENNIE, C.; LAZARUS, L. \& SATYAPAL, K.S. Morfometría y morfología del foramen magnum en la determinación de edad y sexo dentro de la población negra sudafricana mediante tomografía computarizada (TC). Int. J. Morphol., 37(1):251-257, 2018.

RESUMEN: La morfología y morfometría del foramen magnum ayuda a los estudios forenses en la identificación de individuos desconocidos según la edad y el sexo. Además, parámetros del foramen magnum tienen relevancia clínica para los cirujanos en el abordaje transcondilar. Este estudio tuvo como objetivo analizar la morfometría y la morfología del foramen magnum, en relación con la edad y el sexo, dentro de la población negra sudafricana, utilizando imágenes de tomografía computarizada. El uso de imágenes de tomografía computarizada permitió definir diámetros morfométricos precisos utilizando el software SLICER 3-D versión 4.7.0. Las imágenes radiológicas también proporcionan antecedentes de la historia clínica de un paciente. De este modo, se logra el proceso de exclusión con respecto a los pacientes con afecciones patológicas del cráneo. La muestra estudiada incluyó 150 imágenes de tomografía computarizada (93 hombres y 57 mujeres) organizadas según cohortes de edad (niños de 1 a 12 años, adolescentes de 13 a 17 años y adultos de 18 a 25 años). Los parámetros morfométricos que se consideraron fueron: diámetro antero-posterior, diámetro transversal y área del foramen magnum. Las variaciones morfológicas del foramen magnum se observaron simultáneamente entre hombres y mujeres y dentro de los grupos de edad. El objetivo de este estudio fue mejorar los datos sobre los parámetros morfológicos y morfométricos del foramen magnum en la población negra sudafricana. Este estudio también intentó asociar los parámetros morfológicos y morfométricos del foramen magnum con la determinación de la edad y el sexo.

PALABRAS CLAVE: Tomografía computarizada; Morfometría; Morfología; Edad; Sexo.

\section{REFERENCES}

Aragão, J. A.; de Oliveira Pereira, R.; de Moraes, R. Z. C. \& Reis, F. P. Morphological types of foramen magnum. Ann. Res. Rev. Biol., 4(9):1372-8, 2014.

Burdan, F.; Szumio, J.; Walocha, J.; Klepacz, L.; Madej, B.; Dworzanski, W.; Klepacz, R.; Dworzanska, A.; Czekajska-Chehab, E. \& Drop, A. Morphology of the foramen magnum in young Eastern European adults. Folia Morphol. (Warsz), 71(4):205-16, 2012. 
MOODLEY, M.; RENNIE, C.; LAZARUS, L. \& SATYAPAL, K. S. The morphometry and morphology of the foramen magnum in age and sex determination within the South African Black population utilizing computer tomography (CT) scans. Int. J. Morphol., 37(1):251-257, 2019.

Chandramani, B. M.; Nairita, S. \& Ritika, V. Morphological analysis of foramen magnum for gender determination by using computed tomography. J. Oral Med. Oral Surg. Oral Pathol. Oral Radiol., 1(2):51-6, 2015.

Chaurasia, B. D. Human Anatomy. Regional and Applied, Dissection and Clinical. New Delhi, CBS Publishers \& Distributors, 2004.

Chethan, P.; Prakash, K. G.; Murlimanju, B. V.; Prashanth, K. U.; Prabhu, L. V.; Saralaya, V. V.; Krishnamurthy, A.; Somesh, M. S. \& Kumar, C. G. Morphological analysis and morphometry of the foramen magnum: an anatomical investigation. Turk.Neurosurg., 22(4):4169, 2012.

Cirpan, S.; Yonguc, G. N.; Mas, N. G.; Aksu, F. \& Orhan Magden, A. Morphological and morphometric analysis of foramen magnum: an anatomical aspect. J. Craniofac. Surg., 27(6):1576-8, 2016.

Ganapathy, A.; Sadeesh, T. \& Rao, S. Morphometric analysis of foramen magnum in adult human skulls and CT images. Int. J. Curr. Res. Rev., 6(20):11-5, 2014

Gapert, R.; Black, S. \& Last, J. Sex determination from the foramen magnum: Discriminant function analysis in an eighteenth and nineteenth century British sample. Int. Legal Med., 123(1):25:33, 2009.

Gruber, P.; Henneberg, M.; Böni, T. \& Rühli, F. J. Variability of human foramen magnum size. Anat. Rec. (Hoboken), 292(11):1713-9, 2009.

Günay, Y. \& Altinkök, M. The value of the size of foramen magnum in sex determination. J. Clin. Forensic Med., 7(3):147-9, 2000.

Loyal, P.; Ongeti, K.; Pulei, A.; Mandela, P. \& Ogeng'o, J. Short communication: Gender related patterns in the shape and dimensions of the foramen magnum in an adult Kenyan population. Anat. J. Afr., 2(2):138-41, 2013.

Manoel, C.; Prado, F. B.; Caria, P. H. F. \& Groppo, F. C. Morphometric analysis of the foramen magnum in human skulls of brazilian individuals: its relation to gender. Braz. J. Morphol. Sci., 26(2):1048, 2009.

Murshed, K. A.; Çiçekcibas,i, A. E. \& Tuncer, I. Morphometric evaluation of the foramen magnum and variations in its shape: a study on computerized tomographic images of normal adults. Turk. J. Med. Sci., 33:301-6, 2003.

Natsis, K.; Piagkou, M.; Skotsimara, G.; Piagkos, G. \& Skandalakis, P. A morphometric anatomical and comparative study of the foramen magnum region in a Greek population. Surg. Radiol. Anat., 35(10):925-34, 2013.

Pires, L. A. S.; Teixeira, A. R.; Leite, T. F. O.; Babinski, M. A. \& Chagas, C. A. A. Morphometric aspects of the foramen magnum and the orbit in Brazilian dry skulls. Int. J. Med. Res. Health Sci., 5(4):34-42, 2016.

Raikar, N. A.; Meundi, M. A.; David, C. M.; Rao, M. D. \& Jogigowda, S. C. Sexual dimorphism in foramen magnum dimensions in the South Indian population: A digital submentovertex radiographic study. $J$. Forensic Dent. Sci., 8(3):180-1, 2016.

Shaikh, V. G. \& Kulkarni, P. R. A Morphological and morphometric study of foetal and adult, human foramen magnum in relation with age changes, sexual dimorphism and symmetry. Indian J. Basic Appl. Med. Res., 4(2):140-50, 2015.

Sharma, S.; Sharma, A. K.; Modi, B. S. \& Arshad, M. Morphometric evaluation of the foramen magnum and variation in its shape and size: a study on human dried skull. Int. J. Anat. Res., 3(3):1399-403, 2015.

Shepur, M. P.; Magi, M.; Nanjundappa, B.; Havaldar, P. P.; Gogi, P. \& Saheb, S. H. Morphometric analysis of foramen magnum. Int. J. Anat. Res., 2(1):249-55, 2014.

Standring, S. Gray's Anatomy. The Anatomical Basis of Clinical Practice. 41st ed. Philadelphia, Elsevier, 2016.

Uthman, A. T.; Al-Rawi, N. H. \& Al-Timimi, J. F. Evaluation of foramen magnum in gender determination using helical CT scanning. Dentomaxillofac. Radiol., 41(3):197-202, 2012.

Uysal, S.; Gokharman, D.; Kacar, M.; Tuncbilek, I. \& Kosa, U. Estimation of sex by 3D CT measurements of the foramen magnum. J. Forensic Sci., 50(6):1310-4, 2005.
Vedanayagam, T. \& Sathyamurthy, V. Sex determination from foramen magnum measurements - A regional study in Chennai, TN. Indian J. Forensic Community Med., 2(3):179-81, 2015.

Zaidi, S. H. \& Dayal, S. S. Variations in the shape of foramen magnum in Indian skulls. Anat. Anz., 167(4):338-40, 1988.

\section{Corresponding author: \\ Dr. C. Rennie}

Department of Clinical Anatomy

Nelson R Mandela School of Medicine

School of Laboratory Medicine and Medical Science

College of Health Sciences

University of KwaZulu-Natal

Private Bag 7

Congella

4013

SOUTH AFRICA

Email: rennie@ukzn.ac.za

Received: $30-10-2017$

Accepted: 29-01-2018 